\title{
Faktor-Faktor yang Berhubungan dengan Kepatuhan Menggunakan Alat Pelindung Diri (APD) pada Pekerja Proyek Pembangunan PLTGU Muara Tawar (Persero)
}

\author{
Dhesti Nisrina Azizah, Rafiah Maharani Pulungan, Dyah Utari, Afif Amir \\ Amrullah \\ Program Studi Kesehatan Masyarakat, Fakultas Ilmu Kesehatan \\ Universitas Pembangunan Nasional Veteran Jakarta
}

\begin{abstract}
Abstrak
Latar belakang: Faktor perilaku merupakan salah satu permasalahan dalam kepatuhan menggunakan Alat Pelindung Diri (APD) yang dapat mencegah terjadinya kecelakaan kerja. Teori Lawrence Green menjelaskan bahwa perilaku terdiri atas faktor predisposisi, pendukung, dan pendorong. Alat Pelindung Diri (APD) sudah menjadi sebuah pakaian wajib bagi pekerja, terutama bagi pekerja yang bekerja pada wilayah dengan risiko yang tinggi. Tujuan penelitian ini untuk mengetahui faktor-faktor yang memiliki hubungan dengan kepatuhan penggunaan APD pada pekerja Proyek pembangunan PLTGU Muara Tawar PT. Hutama Karya (Persero).

Metode: Penelitian ini merupakan analitik kuantitatif dengan desain potong lintang. Populasi penelitian ini pekerja Proyek PLTGU Muara Tawar PT Hutama Karya yang berada di area STG dan HRSG sebanyak 349 pekerja.

Hasil: Hasil yang didapatkan dalam penelitian ini menunjukkan bahwa 9 pekerja tidak patuh dalam menggunakan APD. Hasil analisis statistik menyimpulkan hubungan pada faktor predisposisi pengetahuan $(P=0,005)$, faktor pemungkin ketersediaan APD $(p=0,003)$, faktor pendorong pengawasan $(p=0,11)$, sementara itu tidak ditemukan adanya hubungan antara variabel usia $(p=0,474)$, sikap $(p=0,157)$, pendidikan $(p=1,000)$ dengan kepatuhan penggunaan APD

Kesimpulan: Disarankan agar perusahaan dapat konsisten memberikan pemahaman mengenai APD dan tegas dalam kepatuhan penggunaan APD

Kata kunci: kepatuhan APD, Pekerja, APD pada pekerja

\section{Factors Related to Compliance of The Using of Personal Protective Equipment (PPE) of The Workers in The Muara Tawar PLTGU Development PT. Hutama Karya (Persero)}

\begin{abstract}
Background: Behavioral factor is one of the problems in compliance with Personal Protective Equipment (PPE) usage which can prevent work accidents. Lawrence Green's theory explains that behavior consists of 3 factors such as predisposing, supporting and driving factors. Personal protective equipment (PPE) has become a mandatory attire for workers, especially for workers who work in high risk areas.

Methods: The purpose of this study was to determine the factors that related to the compliance to wear PPE on the workers of the Muara Tawar PT. Hutama Karya (Persero) project. This research type was quantitative analytic with cross sectional design. The population of this study were 349 workers of the Muara Tawar PLTGU PT Hutama Karya project in the STG and HRSG areas.

Result: The results showed that 9 workers (questionnaire) and 32 workers (observation sheets) did not comply to wear PPE. The results of statistical analysis showed a connection to the predisposing factors of knowledge $(P=0.005)$, the enabling factors for the availability of PPE $(p=0.003)$, and the driving factors for supervision $(p=0.11)$ and there was no connection between the variables of age $(p=0.474)$, attitude $(p=0.157)$, education ( $p=1,000)$ with compliance to wear PPE.

Conclusion: suggested that companies can consistently provide an understanding PPE and be firm in compliance to wear PPE.
\end{abstract}

Key Words: compliance PPE, Workers, PPE on Workers

Korespondensi:Dhesti Nisrina Azizah

Email: Dhesti.Azizah@yahoo.co.id 


\section{PENDAHULUAN}

Pekerja merupakan bagian yang penting dari organisasi perusahaan dalam upaya untuk maju dan berkembang. Badan Pusat Statistik menyebutkan bahwa pada Bulan Februari 2020 terhitung sebanyak 131,03 juta penduduk Indonesia menjadi angakatan tenaga kerja. Jumlah ini mengalami peningkatan 1,67 juta orang dari Bulan Februari $2019^{1}$.

Salah satu aspek yang memiliki peran paling penting dalam perkembangan dan kemajuan suatu industri aspek Keselamatan dan Kesehatan Kerja yang bertujuan sebagai upaya pencegahan kejadian kecelakaan kerja serta penyakit akibat kerja yang berasal dari suatu pekerjaan di lingkungan kerja ${ }^{2}$.

Data BPJS Ketenagakerjaan menunjukkan adanya peningkatan trend kasus kecelakaan kerja yang terjadi. Data tersebut menunjukkan peningkatan kasus kecelakaan kerja pada tahun 2018 yang mencapai 173.105 kasus dari yang sebelumnya pada tahun 2017 sebanyak 123.041 kasus. Setiap tahunnya sekitar dua ratus lima puluh juta kasus occupational accident dan serratus enam puluh juta tenaga kerja mengalami penyakit yang diakibatkan bahaya yang terdapat pada pekerjaan yang dimiliki².

Pada dasarnya kecelakaan kerja dapat diakibatkan karena factor manusia maupun faktor lingkungan kerja, berdasarkan data statistika $80 \%$ faktor manusia (unsafe action) yang menjadi penyebab terjadinya kecelakaan kerja dan 20\% disebabkan oleh faktor lingkungan (unsafe condition) ${ }^{3}$. Unsafe action merupakan faktor utama yang menyebabkan kejadian kecelakaan kerja dan memiliki hubungan erat dengan perilaku manusia terutama dalam melakukan pekerjaannya di tempat kerja ${ }^{4}$.

Kepribadian seseorang menentukan perilaku yang ditimbulkannya. Selain kepribadian faktor lainnya seperti budaya, status sosial, dan pemikiran dapat memengaruhi perilaku seseorang didalam suatu kelompok ${ }^{5}$. Perilaku kesehatan merupakan hasil dari adanya stimulus yang berhubungan dengan penyakit, sakit - sehat, faktor-faktor yang mempengaruhi kesehatan yang berkitan dengan pencegahan dan peningkatan kesehatan. Hal tersebut

diperkuat dengan teori yang menjelaskan bahwa apabila memperhatikan perilaku pada pekerja dapat mencegah kejadian kecelakaan kerja yang mungkin terjadi di tempat kerja ${ }^{6}$. Teori "Preced-Proceed" merupakan salah satu teori yang membahas mengenai faktor yang mempengaruhi perilaku manusia yang telah dikembangkan oleh Lawrence Green pada tahun 1980, model tersebut menjelaskan bahwa perilaku terdiri atas 3 faktor utama yaitu faktor predisposisi (predisposing), pemungkin (enabling), dan pendorong (reinforcing) ${ }^{7}$. Teori Kurt Lewin dalam Notoadmodjo (2019), menjelaskan bahwa interaksi antar individu yang kompleks dengan lingkungan dapat menghasilkan sebuah perilaku seseorang? ${ }^{7}$.

Berdasarkan uraian diatas, maka perlu adanya usaha dalam melindungi serta mencegah pekerja dari segala bahaya dan risiko yang dapat dialami oleh pekerja saat melaksanakan pekerjaannya yang dapat dilakukan mlelaui penggunaan alat pelindung yang sesuai ${ }^{8}$. Alat Pelindung Diri yang selanjutnya disebut APD ialah alat yang berkemampuan untuk dapat memberikan perlindungan pada pekerja secara personal pada saat melakukan pekerjaan dan berfungsi menutup rapat seluruh tubuh pekerja agar terhindar dari bahaya yang terdapat pada lingkungan kerja ${ }^{9}$. Pada pekerja konstruksi tentunya APD merupakan pakaian wajib yang dapat melindungi diri dari sumber bahaya yang berada pada lingkungan kerja. Dalam penggunaannya Alat Pelindung Diri (APD) menjadi opsi terakhir dalam mencegah terjadinya kejadian kecelakaan kerja setelah menghilangkan risiko dan mengendalikan sumber bahaya yang ada ${ }^{10}$. Tidak sedikit perusahaan yang memutuskan untuk merekomendasikan menggunakan Alat Pelindung Diri (APD) untuk mengupayakan proteksi awal terhadap adanya bahaya potensi terjadinya kasus kecelakaan di tempat kerja dan penyakit yang diakibatkan pekerjaan yang berada di area tempat bekerja ${ }^{11}$.

Faktor perilaku merupakan salah satu permasalahan perilaku kepatuhan dalam penggunaan Alat Pelindung Diri (APD) yang dapat digunakan dalam pencegahan 
kecelakaan kerja ${ }^{12}$. Berdasarkan penelitianpenelitan yang telah dilakukan bahwa patuh atau tidaknya para tenaga kerja dengan ketentuan dan aturan mengenai pemakaian alat pelindung diri sesuai dengan pekerjaannya dapat bergantung pada sejumlah faktor diantaranya yaitu tingkat pengetahuan ${ }^{13}$, pelatihan ${ }^{14}$, Sikap ${ }^{15}$.

Pemerintah menegaskan dalam permenakertrans tahun 2010 pada pasal 3 bahwasannya setiap perusahaan diwajibkan menyediakan Alat Pelindung Diri (APD) yang sesuai dengan peraturan yang telah ditetapkan secara cuma-cuma kepada seluruh pekerja yang berada di tempat kerja ${ }^{16}$. selain itu, dalam penggunaannya Alat Pelindung Diri (APD) harus memiliki kondisi yang baik, menyesuaikan dengan Standar Operasional Prosedur (SOP) dan menyesuaikan dengan kebutuhan dari jenis pekerjaan yang dilakukan ${ }^{17}$.

Berdasarkan hasil studi awal yang dilakukan dengan pengamatan lapangan, masih sering ditemukan beberapa pekerja yang dengan sengaja maupun tidak sengaja tidak patuh dalam menggunakan alat pelindung diri yang tepat sesuai dengan bahaya dan risiko dari pekerjaan yang sedang dilaksanakan. Mengingat bahwa lingkungan kerja di Pembangunan Pembangkit Listrik Tenaga Gas Uap (PLTGU) Muara Tawar PT. Hutama Karya memiliki bahaya dan risiko yang dapat dikatakan cukup banyak dan tinggi, seperti tertimpa benda, tertusuk, terpeleset, tersayat benda tajam, dan terjatuh dari ketinggian. Dengan pekerja tidak menggunakan APD maka akan meningkatkan risiko terjadinya cidera ringan hingga berat bahkan berujung pada kecelakaan kerja.

\section{METODE}

Pada penelitian ini digunakan analitik kuantitatif sebagai jenis penelitian dengan menggunakan metode potong lintang. Penelitian ini memiliki populasi yaitu seluruh pekerja proyek yang berada pada HRSG dan STG Pembangunan Pembangkit Listrik Tenaga Gas Uap (PLTGU) Muara Tawar PT. Hutama Karya. Penelitian berlangsung dari bulan Oktober - Januari 2021. Penelitian ini menganalisis sebanyak 60 responden yang dipilih berdasrkan kriteria penilaian tertentu melalui teknik sampling purposive untuk menentukan wilayah penelitian dan random sampling untuk mendapatkan responden penelitian serta menggunakan kriteria inklusi dan ekslusi. Variabel dependen dalam penelitian ini yaitu perilaku kepatuhan penggunaan Alat Pelindung Diri (APD), sedangkan variabel independen terdiri atas tiga faktor yaitu faktor predisposisi (usia, pendidikan, pengetahuam, sikap), faktor pemungkin (ketersediaan APD), dan faktor pendorong (pengawasan).

Metode pengumpulan data menggunakan data sekunder seperti pelingkupan area kerja dan jumlah pekerja, sedangkan data primer didapatkan dengan wawancara menggunakan lembar kuesioner yang sudah dilakukan uji validitas dan reliabilitas sebelumnya. Analisis data yang digunakan untuk menunjukkan adanya hubungan antar variable adalah anlisis bivariat menggunakan Chi-Square Test.

HASIL

Analisis Univariat

Analisis pada tingkat univariat mengetahui jumlah dan sebaran dari setiap dalam penelitian memiliki tujuan untuk dapat variabel yang akan diteliti.

Tabel 1. Karakteristik Pekerja Pembangunan Pembangkit Listrik Tenaga Gas Uap (PLTGU) Muara Tawar PT. Hutama Karya

\begin{tabular}{lcc}
\hline Variabel & Jumlah (n) & Persentase (\%) \\
\hline Dependen & & \\
\hline Kepatuhan Penggunaan APD & & \\
(Lembar Kuesioner) & 51 & $85 \%$ \\
Patuh & 9 & $15 \%$ \\
Tidak Patuh & & \\
\hline
\end{tabular}

Kepatuhan Penggunaan APD

(Lembar Observasi) 


\begin{tabular}{lcc} 
Patuh & 28 & $46,7 \%$ \\
Tidak Patuh & 32 & $53,3 \%$ \\
\hline Independen & & \\
\hline Usia & & \\
Muda & 31 & $51,7 \%$ \\
Tua & 29 & $48,3 \%$ \\
\hline Pengetahuan & \\
Tidak Baik & 15 & $25 \%$ \\
Baik & 45 & $75 \%$ \\
\hline Sikap & & \\
Negatif & 26 & $43,3 \%$ \\
Positif & 34 & $56,7 \%$ \\
Ketersediaan APD & & \\
Tidak Cukup Tersedia & 25 & $41,7 \%$ \\
Cukup Tersedia & 35 & $58,3 \%$ \\
\hline Pengawasan & & \\
Kurang Baik & 29 & $48,3 \%$ \\
Baik & 31 & $51,7 \%$ \\
\hline Pendidikan & & \\
Rendah & 20 & $66,7 \%$ \\
Tinggi & 40 & \\
\hline
\end{tabular}

Tabel 1 menunjukkan hasil berdasarkan kuesioner mayoritas respondenpatuh dalam penggunaan APD (85\%), apabila berdasarkan lembar observasi didapati sebanyak 32 responden (53\%) tidak patuh dalam penggunaan APD. Frekuensi terbanyak usia responden masuk kedalam kategori usia muda $(51,7 \%)$, sampel penelitian dengan tingkat pengetahuan yang baik berjumlah 45 responden (75\%), mayoritas responden memiliki sikap positif sebanyak 34 responden (56,7\%), persepsi ketersediaan APD sebanyak 35 responden $(58,3 \%)$ merasa cukup tersedia, mayoritas responden beranggapan pengawasan yang dilakukan sudah baik sebanyak 31 responden $(51,7 \%)$, mayoritas tingkat Pendidikan responden masuk kedalam kategori tinggi sebanyak 40 responden $(66,7 \%)$.

\section{Analisis Bivariat}

Analisis pada tingkat bivariat memiliki tujuan mengidentifikasi keterkaitan antara variabel terikat dengan variabel bebas dan dilaksanakan dengan menggunakan $\mathrm{Chi}$ Square Test.

Tabel 2. Hubungan Antara Faktor Predisposisi dengan Kepatuhan Penggunaan Alat Pelindung Diri (APD) pada Pekerja Pembangunan Pembangkit Listrik Tenaga Gas Uap (PLTGU) Muara Tawar PT. Hutama Karya

\begin{tabular}{|c|c|c|c|c|c|c|c|c|c|}
\hline \multirow{3}{*}{ No } & \multirow{3}{*}{ Variabel } & \multicolumn{6}{|c|}{ Kepatuhan Penggunaan APD (kuesioner) } & \multirow{3}{*}{$\begin{array}{c}P \text { - } \\
\text { Value }\end{array}$} & \multirow{3}{*}{$\begin{array}{l}\text { OR } \\
90 \% \mathrm{CI}\end{array}$} \\
\hline & & \multicolumn{2}{|c|}{ Tidak Patuh } & \multicolumn{2}{|c|}{ Patuh } & \multicolumn{2}{|c|}{ Total } & & \\
\hline & & $\mathbf{N}$ & $\%$ & $\mathbf{N}$ & $\%$ & $\mathbf{N}$ & $\%$ & & \\
\hline \multirow[t]{3}{*}{1.} & Usia & & & & & & & & \\
\hline & Muda & 6 & 19,4 & 25 & 80,6 & 31 & 100 & & 2.080 \\
\hline & Tua & 3 & 10,3 & 26 & 89,7 & 29 & 100 & 0,474 & $\begin{array}{c}(0,468- \\
9,235)\end{array}$ \\
\hline \multirow[t]{3}{*}{2.} & Pengetahuan & & & & & & & & \\
\hline & Tidak Baik & 6 & 40 & 9 & 60 & 15 & 100 & & 9,333 \\
\hline & Baik & 3 & 6,7 & 42 & 93,3 & 45 & 100 & 0,005 & $\begin{array}{c}(1,958- \\
44.493)\end{array}$ \\
\hline \multirow[t]{3}{*}{3.} & Sikap & & & & & & & & \\
\hline & Negatif & 6 & 23,1 & 20 & 76,9 & 26 & 100 & & 3,100 \\
\hline & Positif & 3 & 8,8 & 31 & 91,2 & 34 & 100 & 0,157 & $\begin{array}{c}(0,695- \\
13,832)\end{array}$ \\
\hline
\end{tabular}




\begin{tabular}{ccccccccc}
\hline 4. Pendidikan & & & & & & & \\
Rendah & 3 & 15 & 17 & 85 & 20 & 100 & 1,000 \\
Tinggi & 6 & 15 & 34 & 85 & 40 & 100 & 1,000 & $\begin{array}{c}(0,222- \\
4,496)\end{array}$ \\
\hline
\end{tabular}

Tabel 2 menunjukkan proporsi pekerja dengan usia muda untuk tidak mematuhi penggunaan Alat Pelindung Diri (APD) lebih besar apabila dibandingkan dengan proporsi pekerja dengan usia tua sehingga didapatkan nilai nilai $p$ value sebesar 0,474 $(\mathrm{OR}=2,080)$ dengan begitu maka Ho diterima, atau dapat dikatakan tidak ditemukannya hubungan yang bermakna antara faktor variabel usia dengan kepatuhan penggunaan Alat Pelindung Diri (APD). Pada variabel pengetahuan ditemukan terdapat 15 responden yang memiliki tingkat pengetahuan yang tidak baik, 6 diantaranya tidak patuh dalam penggunaan Alat Pelindung Diri (APD) sehingga didapatkan hasil sebesar 0,005 (OR $=9,333)$, yang berarti Ho ditolak dengan kata lain ada keterkaitan yang bermakna antara faktor pengetahuan yang dimiliki responden dengan kepatuhan penggunaan Alat Pelindung Diri (APD). Pada variabel sikap menunjukkan proporsi pekerja yang memiliki sikap negatif dalam kepatuhan menggunakan Alat Pelindung Diri (APD) lebih besar apabila dibandingkan dengan proporsi pekerja yang memiliki sikap positif sehingga didapati $p$ value $0,157(\mathrm{OR}=3,100)$ dengan begitu dapat dinyatakan bahwa Ha ditolak dan $\mathrm{H} 0$ diterima hal ini berarti bahwa hubungan antara variable kepatuhan penggunaan APD dengan variable sikap dari pekerja merupakan hubungan yang tidak bermakna. Pada variabel pendidikan menunjukkan proporsi reponden dengan kategori pendidikan yang rendah dan tidak patuh dalam penggunaan Alat pelindung Diri (APD) lebih kecil apabila dibandingkan dengan proporsi pekerja yang memiliki tingkat pendidikan yang tinggi dan didapatkan nilai $p$ value sebesar $1,000(\mathrm{OR}=1,000)$ dengan begitu ditemukan bahwa H0 diterima sehingga hubungan antara tingkat Pendidikan dan patuhnya pekerja dalam menggunakan APD merupakan hubungan yang tidak bermakna.

Tabel 3. Hubungan Antara Faktor Pemungkin dengen Kepatuhan Pengguaan Alat Pelindung Diri (APD) pada pekerja Pembangunan Pembangkit Listrik Tenaga Gas Uap (PLTGU) Muara Tawar PT. Hutama Karya

\begin{tabular}{|c|c|c|c|c|c|c|c|c|c|}
\hline \multirow{3}{*}{ No } & \multirow{3}{*}{ Variabel } & \multicolumn{6}{|c|}{ Kepatuhan Penggunaan APD (kuesioner) } & \multirow{3}{*}{$\begin{array}{l}P \text { - } \\
\text { Value }\end{array}$} & \multirow{3}{*}{$\begin{array}{l}\text { OR } \\
90 \% \text { CI }\end{array}$} \\
\hline & & \multicolumn{2}{|c|}{ Tidak Patuh } & \multicolumn{2}{|c|}{ Patuh } & \multicolumn{2}{|c|}{ Total } & & \\
\hline & & $\mathbf{N}$ & $\%$ & $\mathbf{N}$ & $\%$ & $\mathbf{N}$ & $\%$ & & \\
\hline \multirow[t]{3}{*}{1.} & Ketersediaan APD & & & & & & & & \\
\hline & Tidak cukup tersedia & 8 & 32 & 17 & 68 & 25 & 100 & & 16,000 \\
\hline & Cukup tersedia & 1 & 2,9 & 34 & 97,1 & 35 & 100 & 0,003 & $\begin{array}{l}(1,847- \\
138,577)\end{array}$ \\
\hline
\end{tabular}

Pada tabel tiga angka $p$ value yang didapatkan adalah sebesar 0,003 (OR = 16,000), yang berarti Ha diterima sehingga dapat dikatakan bahwa keterkaitan antar variable yakni ketersediaan Alat Pelindung Diri (APD) dengan kepatuhan dalam memakai Alat Pelindung Diri (APD) yang ditentukan merupakan hubungan yang bermakna. Pekerja yang memiliki persepsi perusahaan tidak cukup menyediaakan Alat Pelindung Diri (APD) memiliki risiko 16 kali lebih besar untuk memiliki sikap tidak mematuhi ketentuan dalam menggunakan APD dibandingkan dengan pekerja yang memiliki persepsi perusahaan cukup menyediakan Alat Pelindung Diri (APD) bagi pekerja. 
Tabel 4. Hubungan Antara Faktor Pendorong dengen Kepatuhan Pengguaan Alat Pelindung Diri (APD) pada pekerja Pembangunan Pembangkit Listrik Tenaga Gas Uap (PLTGU) Muara Tawar PT. Hutama Karya

\begin{tabular}{|c|c|c|c|c|c|c|c|c|c|}
\hline \multirow{3}{*}{ No } & \multirow{3}{*}{ Variabel } & \multicolumn{6}{|c|}{ Kepatuhan Penggunaan APD (kuesioner) } & \multirow{3}{*}{$\begin{array}{l}P \text { - } \\
\text { Value }\end{array}$} & \multirow{3}{*}{$\begin{array}{l}\text { OR } \\
90 \% \mathrm{CI}\end{array}$} \\
\hline & & \multicolumn{2}{|c|}{ Tidak Patuh } & \multicolumn{2}{|c|}{ Patuh } & \multicolumn{2}{|c|}{ Total } & & \\
\hline & & $\mathbf{N}$ & $\%$ & $\mathbf{N}$ & $\%$ & $\mathbf{N}$ & $\%$ & & \\
\hline \multirow[t]{3}{*}{1.} & Pengawasan & & & & & & & & \\
\hline & Kurang baik & 8 & 27,6 & 21 & 72,4 & 29 & 100 & & 11,429 \\
\hline & Baik & 1 & 3,2 & 30 & 96,8 & 31 & 100 & 0,011 & $\begin{array}{l}(1,328- \\
98,344)\end{array}$ \\
\hline
\end{tabular}

Tabel 4 menunjukkan nilai $p$ value sebesar 0,011 (OR = 11,429), yang berarti Ho ditolak dengan kata lain terdapat hubungan yang signifikan antara faktor pengawasan dengan kepatuhan penggunaan Alat Pelindung Diri (APD). Pekerja yang memiliki persepsi pengawasan kurang baik memiliki risiko 11,429 kali lebih besar untuk memiliki sikap tidak patuh pada ketentuan mengenai pemakaian APD saat bekerja, sedangkan pekerja yang memiliki persepsi pengawasan yang baik sebagian besarnya mematuhi ketentuan mengenai pemakaian APD.

\section{PEMBAHASAN}

Hubungan usia pekerja dengan kepatuhan penggunaan Alat Pelindung Diri (APD)

Setelah dilakukan uji dan analisis menggunakan uji statistik penelitian ini tidak dapat membuktikan hipotesis atau tidak ditemukannya hubungan antara variabel tingkat usia dengan perilaku kepatuhan dalam penggunaan Alat Pelindung Diri (APD). Dapat dilihat pada realitanya, perbandingan kepatuhan penggunaan APD pada usia muda dengan usia tua hampir memiliki tingkatan persentase yang sama sehingga hal tersebut menjadikan faktor usia tidak memiliki perbedan yang signifikan.

Hasil penelitian ini diperkuat dengan Dyah (2014) yang mengatakan tidak ditemukannya keterkaitan antara variabel usia dengan perilaku kepatuhan penggunaan APD pada pekerja dengan hasil nilai $p$ value sebesar 1,000. Penelitian yang sama dilakukan pada pekerja PT. Liku Telaga bagian unit produksi alumunium sulfat, pada penelitian tersebut peneliti tidak dapat membuktikan hipotesisnya yang berarti tidak ada hubungan antara variabel tingkat usia dengan perilaku kepatuhan penggunaaan APD pada tenaga kerja ${ }^{18}$.
Hubungan pengetahuan pekerja dengan kepatuhan penggunaan Alat Pelindung Diri (APD)

Setelah dilakukan uji statistik penelitian ini dapat membuktikan hasil hipotesisnya, yaitu ditemukan hubungan yang bermakna antara variabel tingkat pengetahuan pekerja proyek dengan perilaku kepatuhan dalam penggunaan APD. Semakin baik dan tinggi tingkat pengetahuan seseorang maka perilaku yang dihasilkan akan semakin positif ${ }^{14}$. Hal tersebut dapat terjadi dikarenakan pengetahuan pekerja menjadi sebuah dasar dalam sebuah perilaku yang dihasilkan, seperti pada pekerja dengan tingkat tingkat pengetahuan yang baik cenderung memiliki kesadaran dan level kewaspadaan yang lebih tinggi dibandingkan dengan pekerja yang memiliki tingkat pengetahuan yang kurang baik. Sehingga, pada pekerja yang memiliki tingkat pengetahuan tinggi dapat memutuskan sikap dan perilaku untuk patuh dalam penggunaan Alat Pelindung Diri (APD).

Sejalan dengan penelitian Nurdiani \& Krianto tahun 2019 yang mengatakan ditemukannya keterkaitan antara variabel pengetahuan dan tingkat kepatuhan dalam penggunaan APD yang ditunjukkan dengan nilai $\mathrm{p}$ yang didapatkan adalah $0,051(\mathrm{OR}=$ 1,729) ${ }^{19}$. Dalam Yenni (2020), didapatkan hubungan antara variabel pengetahuan dengan tingkat kepatuhan penggunaan Alat Pelindung Diri (APD) dengan nilai $p$ value sebesar 0,031. Pembuktian hipotesa sebelumnya didapati hubungan yang ditunjukkan antara tingkat pengetahuan pekerja industri dengan penggunaan Alat Pelindung Diri (APD) memiliki signifikansi yang tinggi dengan nilai $p$ value sebesar 0,02 $(\mathrm{OR}=1,93)$, responden dengan pengetahuan yang baik berpeluang 1,93 kali lebih besar 
untuk dapat patuh dalam perilaku penggunaan $\mathrm{APD}^{20}$. Alfarisi (2018) mengemukakan dalam penelitiannya didapatkan keterkaitan antara tingkat pengetahuan pekerja dengan kepatuhan pemakaian APD dengan nilai $p$ value sebesar $0,027(\mathrm{OR}=4,540)^{13}$.

\section{Hubungan sikap pekerja dengan kepatuhan penggunaan Alat Pelindung Diri (APD)}

Setelah dilakukan uji statistik penelitian ini tidak dapat membuktikan hipotesinya atau tidak terdapat hubungan yang bermakna antara variabel sikap dengan kepatuhan penggunaan Alat Pelindung Diri (APD) pada pekerja proyek. Pada kondisi lapangan, mayoritas pekerja memiliki sikap positif dalam menggunakan APD, hal tersebut dapat disebabkan oleh beberapa faktor lainnya yang dapat merubah sikap seseorang seperti faktor pengetahuan, ketersediaan, dan pengawasan. Kondisi tersebut diperkuat dengan pernyataan Alfirdha \& Nuraeni (2018), yang menyatakan bahwa dalam pelaksanaannya sikap seseorang membutuhkan sebuah faktor pendukung lainnya. Seseorang akan membentuk sikap secara utuh apabila memenuhi tiga komponen yaitu keyakinan atau pemikiran, emosional atau penilaian terhadap objek, dan kecenderungan untuk dapat bertindak ${ }^{21}$.

Hal tersebut telah dikatakan dalam peneletian yang dilakukan pada pekerja warehouse, yang menyatakan tidak ditemukannya keterkaitan antara variabel sikap dengan perilaku pekerja dalam penggunaan Alat Pelindung Diri (APD) dan didapatkan nilai $p$ value sebesar $1,000^{21}$. Hal tersebut juga disampaikan oleh penelitian lain pada tahun 2019 yang mendapatkan nilai $p$ value sebesar 0,903 ( $\mathrm{OR}=1,357)$ yang memiliki makna bahwa Ho diterima, tidak ada hubungan antara variabel sikap dengan perilaku kepatuhan penggunaan APD pada pekerja. Diperkuat oleh penelitian lainnya yang mengemukakan tidak adanya keterkaitan antara variabel sikap dengan kepatuhan penggunaan Alat Pelindung Diri (APD) dengan nilai $p$ value sebesar 0,627.
Hubungan tingkat pendidikan pekerja dengan kepatuhan penggunaan Alat Pelindung Diri (APD)

Setelah dilakukan uji statistik penelitian yang dilakukan ini tidak dapat membuktikan hipotesisnya dengan maksud Ho diterima, tidak terdapat hubungan yang signifikan antara variabel tingkat pendidikan dengan perilaku kepatuhan penggunaan Alat Pelindung Diri (APD) pada pekerja proyek. Hal tersebut dapat terjadi dikarenakan pada pekerja yang memiliki tingkat pendidikan tinggi belum tentu paham mengenai perilaku patuh dalam pengggunaan Alat Pelindung Diri (APD). Selain itu, tidak sedikit pekerja proyek yang telah mengikuti ekstensi pelatihan mengenai Kesehatan dan Keselamatan Kerja (K3) diluar pendidikan formal yang dapat melatar belakangi pekerja dalam berperilaku patuh dalam penggunaan Alat Pelindung Diri (APD).

Sama halnya dengan penelitian yang sebelumnya telah dilaksanakan oleh Elwindra \& Sari (2019) penelitian didapatkan nilai $\mathrm{p}$ adalah 0,877 dan memiliki makna tidak adanya keterkaitan yang berarti antara variabel tingkat pendidikan yang dimiliki pekerja dengan tindakan pekerja proyek dalam mematuhi penggunaan APD. Hal yang sama dikemukakan oleh penelitian yang dilakukan oleh Aprinita et al (2017) yang mendapatkan nilai $p$ value sebesar 1,000 yang berarti tidak ditemukannya keterkaitan antara tingkat pendidikan dengan kepatuhan penggunaan Alat Pelindung Diri (APD) ${ }^{22}$.

Hubungan ketersediaan Alat Pelindung Diri (APD) di tempat kerja dengan kepatuhan penggunaan Alat Pelindung Diri (APD)

Setelah dilakukan uji statistik penelitian ini dapat membuktikan hipotesisnya, atau dapat dinyatakan bahwa Ho ditolak, yaitu ditemukan hubungan yang signifikan antara variabel ketersediaan APD dengan tingkat kepatuhan penggunaan APD pada pekerja proyek. Dengan begitu dapat dinyatakan bahwa pekerja yang memiliki persepsi perusahaan tidak cukup menyediakan APD 16 kali lebih besar untuk tidak dapat mematuhi penggunaan APD pada saat melakukan pekerjaanya atau berada di area kerja. 
Salah satu faktor pendukung dalam konsep perilaku kepatuhan seseorang dalam menggunakan Alat Pelindung Diri yaitu ketersediaan APD itu sendiri yang seharusnya sudah disediakan oleh pihak perusahaan. Hal tersebut telah dicantumkan dalam peraturan pemerintah ketenagakerjaan dan transmigrasi pada Pasal 2 tahun 2010 tentang Alat Pelindung Diri yang berbunyi "Pengusaha wajib menyediakan APD bagi pekerja/buruh di tempat kerja" maka dari itu setiap perusahaan memiliki kewajiban untuk memastikan keckupan dan ketersediaan Alat Pelindung Diri (APD) yang layak bagi pekerja. Hal tersebut dapat terjadi dikarenakan apabila pekerja sudah memiliki sikap yang positif dalam penggunaan APD namun tidak didukung dengan ketersediaan APD dari perusahaan maka hal tersebut tentu dapat menyebabkan pekerja atau buruh proyek untuk tidak mematuhi penggunaan APD. Persepsi pekerja mengenai ketersediaan Alat Pelindung Diri (APD) juga dapat dipengaruhi oleh faktor lainnya seperti pengawasan, inspeksi, atau sistem pelaporan dan pencatatan terhadap Alat Pelindung Diri (APD) pada pekerja.

Hal tersebut sebelumnya telah dikemukakan oleh Prasetyo (2015) yang menyatakan ada keterkaitan antara variabel ketersediaanAPD dengan nilai $p$ value sebesar $0,009^{23}$. Sama hal nya dengan pernyataan Elwindra \& Sari (2019) menyatakan bahwa Ho ditolak atau terdapat hubungan yang signifikan antara ketersediaan APD dengan perilaku patuh dalam menggunakan APD dengan nilai $p$ value $0,047^{10}$. Namun hal tersebut tidak sesuai dengan penelitian yang sebelumnya telah dilakukan oleh Aprinita et al., (2017) yang menyatakan tidak ada keterkaitan yang bermakna antara ketersediaan APD dengan perilaku kepatuhan penggunaan Alat Pelindung Diri (APD) dengan nilia $p$ value sebesar $0,756^{22}$.

\section{Hubungan pelaksanaan pengawasan dengan kepatuhan penggunaan Alat Pelindung Diri (APD)}

Setelah dilakukan uji statistik penelitian ini dapat membuktikan hipotesisnya, atau dapat dinyatakan bahwa Ho ditolak, yaitu ditemukan hubungan bermakna antara variabel pengawasan dengan variabel kepatuhan pekerja dalam menggunakan APD pada pekerja proyek. Dengan begitu dapat dinyatakan bahwa pekerja yang memiliki persepsi perusahaan kurang dalam melakukan pengawasan 11,429 kali lebih besar untuk tidak patuh dalam penggunaan Alat Pelindung Diri (APD) saat bekerja.

Divisi HSE pada pekerja proyek memiliki beberapa tupoksi salah satunya yaitu melakukan pengawasan terhadap Keselamatan dan Kesehatan Kerja (K3). Dalam pelaksanaannya pelaksanaan pengawasan K3 Proyek Pembangunan PLTGU Muara Tawar PT. Hutama Karya (persero) sudah dilakukan dengan cukup baik. Hal tersebut dapat terlihat pada saat Supervisor divisi HSE melakukan pengawasan dan teguran pekerja cukup kooperatif dalam menerima teguran tersebut dan memperbaiki sehingga faktor pengawasan memiliki hubungan dengan perilaku kepatuhan penggunaan Pelindung APD. Apabila ditemukan pekerja yang tidak patuh dalam penggunaan APD pada saat bekerja hal tersebut dapat terjadi dikarenakan wilayah atau area yang cukup luas dan memiliki jenis pekerjaan yang beragam sehingga jumlah sumber daya manusia Supervisor HSE yang bertanggung jawab pada area tersebut

Hal tersebut berbanding lurus dengan penelitian Edigan, Sari, \& Amalia (2019) yang membuktikan adanya keterkaitan di antara variabel persepsi terhadap upaya monitoring atau pengawasan dengan Tindakan pekerja dalam kaitannya dengan kepatuhan dalam mengenakan APD yang diwajibkan dengan nilai POR 4,167 dan memiliki makna bahwa subjek penelitian yang tidak dimonitoring atau diawasi lebih berisiko 4,167 kali tidak mematuhi ketentuan penggunaan APD jika dibandingkan dengan subjek dengan pengawasan atau upaya monitoring ${ }^{24}$. Hal tersebut diperkuat kembali dengan penelitian yang telah dilakukan oleh Lobis et al (2020) yang menyimpulkan bahwa ada pengaruh yang signifikan antara variabel pengawasan dengan kepatuhan penggunaan APD dengan nilai $p$ value $0,01^{25}$. 


\section{KESIMPULAN}

Penelitian menunjukkan adanya hubungan yang signifikan antara beberapa variable bebas yakni: faktor predisposisi (pengetahuan), faktor pemungkin (Ketersediaan APD), dan faktor pendorong (Pengawasan) dengan kepatuhan pekerja dalam penggunaan alat pelindung diri pada pekerja di proyek pembangunan di pembangkit listrik tenaga gas uap dalam Muara Tawar PT. Hutama Karya (persero). Selain itu, penelitian ini juga menemukan bahwa antara variabel usia, pendidikan dan sikap dengan variable kepatuhan penggunaan Alat Pelindung Diri (APD) pada pekerja proyek pembangunan di PLTGU Muara Tawar PT. Hutama Karya (persero) tidak memiliki hubungan yang bermakna.

Selanjutnya, peneliti menyarankan agar pihak perusahaan dapat melakukan kegiatan penyuluhan secara konsisten mengenai penerapan upaya keselamatan dan Kesehatan dalam bekerja bagi para pekerja proyek, melakukan inspeksi kelayakan APD pekerja, serta melakukan sistem punishment and rewarding kepada pekerja yang tidak patuh atau patuh dalam menggunakan Alat Pelindung Diri (APD) di tempat kerja. Dengan begitu, maka dapat meningkatkan kepatuhan penggunaan alat pelindung diri yang sesuai di tempat kerja pada pekerja sehingga pada akhirnya dapat mencegah serta mengurangi risiko terjadinya kecelakaan kerja.

\section{DAFTAR PUSTAKA}

1. Badan Pusat Statistik. Keadaan Ketenagakerjaan Indonesia Februari 2020. Ber Resmi Stat. 2020;(40):20.

2. Haworth N, Hughes S. The International Labour Organization. Handbook of Institutional Approaches to International Business. 2012. 204 $218 \mathrm{p}$.

3. Erlani, Anugrah S. HUBUNGAN PERILAKU PEKERJA DENGAN PENGGUNAAN ALAT PELINDUNG DIRI (APD) DI PABRIK PENGGILINGAN PADI KABUPATEN SIDRAP. 2018;18(2):140-5.

4. Pratama AK. Hubungan Karakteristik Pekerja Dengan Unsafe Action Pada
Tenaga Kerja Bongkar Muat Di Pt. Terminal Petikemas Surabaya. Indones J Occup Saf Heal. 2015;4(1):64.

5. Nuqul F. Perbedaan kepatuhan terhadap aturan tinjauan kepribadian introvert-ekstrovert, jenis kelamin dan lama tinggal di Ma'had Ali Universitas Islam Negeri (UIN) Malang. Psikoislamika. 2007;4(2):229-43.

6. Dahyar CP. PERILAKU PENGGUNAAN ALAT PELINDUNG DIRI PADA PEKERJA PT . X BEHAVIOR OF PERSONAL PROTECTIVE EQUIPMENT USE IN PT . X. 2014;178-87.

7. Notoadmodjo. Pengantar Ilmu Perilaku Kesehatan. Jakarta: Rineka Cipta. 2019.

8. Puji AD, Kurniawan B, Jayanti S. FAKTOR FAKTOR YANG BERHUBUNGAN DENGAN KEPATUHAN PENGGUNAAN ALAT PELINDUNG DIRI PADA PEKERJA REKANAN (PT. X) DI PT INDONESIA POWER UP SEMARANG. 2017;5:20-31.

9. Fauzan A. Kajian Penggunaan Alat Pelindung Diri (APD) Dengan Kejadian Kecelakaan Kerja Pemandu. 2018;1-38.

10. Elwindra NYS. Jurnal Persada Husada Indonesia Faktor-Faktor Yang Berhubungan Dengan Perilaku Penggunaan APD Pada Pekerja Di Proyek Lippo Thamrin Office Tower PT Wijaya Karya Jakarta Factors Connected With The Behavior Of Use Of APD On Workers In Lippo Thamrin Office To. 2019;6(23):1-10.

11. Yuliani I, Amalia R. ARTIKEL PENELITIAN Faktor-Faktor yang Berhubungan Dengan Perilaku Pekerja dalam Penggunaan Alat Pelindung Diri ( APD ). 2019;08(01).

12. Solekhah SA. Faktor Perilaku Kepatuhan Penggunaan Apd Pada Pekerja Pt $X . \quad J$ PROMKES. 2018;6(1):1.

13. Alfarisi R. Hubungan Antara Pengetahuan dan Sikap dengan 
Pemakaian Alat Pelindung Diri pada Pekerja Peternakan Sapi dan Kambing Di Kecamatan Cikalon Kabupaten Tasikmalaya. 2018;7:212-7.

14. Yenni M. Faktor-Faktor Yang Mempengaruhi Perilaku Penggunaan Alat Pelindung Diri (Apd) Pada Pekerja Perkebunan Sawit Pt. Kedaton Mulia Primas Jambi Tahun 2017. Care J Ilm Ilmu Kesehat. 2020;8(1):84.

15. Fazni D. Kurusi, Rahayu H. Akili MIP. Hubungan Antara Pengetahuan Dan Sikap Dengan Kepatuhan Penggunaan Alat Pelindung Diri (Apd) Pada Petugas Penyapu Jalan Di Kecamatan Singkil Dan Tuminting. Kesmas. 2020;9(1):45-51.

16. Menteri Tenaga Kerja dan Transmigrasi. Peraturan Menteri Tenaga Kerja dan Transmigrasi Republik Indonesia. Peratur Menteri tenaga Kerja dan Transm [Internet]. 2010; VII(8):1-69. Available from: https://indolabourdatabase.files.wordp ress.com/2018/03/permenaker-no-8tahun-2010-tentang-apd.pdf

17. Mashfufa EW, Kurnia AD, Ashari F. HUBUNGAN PENGETAHUAN DAN KEPATUHAN MENGGUNAKAN ALAT PELINDUNG DIRI PADA PEKERJA KONTRUKSI DI PT $\mathrm{X}$ KABUPATEN PASURUAN. 2017;2(6).

18. Dyah KSP. Analysis of Factor Related To Compliance of Using Personal Protective Equipment. Indones $\mathrm{J}$ Occup Saf Heal. 2014;6:312-22.

19. Nurdiani CU, Krianto T. Kepatuhan Penggunaan Alat Pelindung Diri (Apd) Di Laboratorium Pada Mahasiswa Prodi Diploma Analis Kesehatan Universitas Mh Thamrin. J Ilm
Kesehat. 2019;11(2):88-93.

20. Rahmiati, Andriaty SN, Andri. HUBUNGAN PENGETAHUAN DENGAN PENGGUNAAN ALAT PELINDUNG DIRI PADA PEKERJA INDUSTRI BATU BATA. 2019;6(April):152-9.

21. Alfirdha B, Nuraeni T. Hubungan Faktor Predisposisi dengan Perilaku Penggunaan Alat Pelindung Diri pada Pekerja PT. Elnusa TBK Warehouse Karangampel Relationship of Predisposing Factors with the Behavior of Use of Personal Protective Equipment at PT. Gudang Elnusa TBK Karangamp. 2018;3(3):101-10.

22. Rokok P, Lajar P, Semarang DI, Asia D. Faktor - Faktor Yang Berhubungan Dengan Perilaku Penggunaan Alat Pelindung Diri (Apd) Pada Karyawan Pabrik Rokok Praoe Lajar Di Semarang. J Kesehat Masy. 2017;5(5):1054-62.

23. Eko Prasetyo. Pengaruh Pengetahuan, Sikap, dan Keterediaan Alat Pelindung Diri (APD) Terhadap Kepatuhan Dalam Menggunakan APD di Unit Coacting PT. Pura Barutama Kudus $\cdot$. 2015;2(3).

24. Edigan F, Purnama Sari LR, Amalia R. Hubungan Antara Perilaku Keselamatan Kerja Terhadap Penggunaan Alat Pelindung Diri (APD) Pada Karyawan PT Surya Agrolika Reksa Di Sei. Basau. J Saintis. 2019;19(02):61.

25. Lobis YB, Ariyanto D, Warsini W. Pengaruh Pengawasan Terhadap Kepatuhan Penggunaan Alat Pelindung Diri Di Pt Jamu Air Mancur Palur. PLACENTUM J Ilm Kesehat dan Apl. 2020;8(1):31. 